National Water-Quality Assessment Program

\title{
Digital Spatial Data for Predicted Nitrate and Arsenic Concentrations in Basin-Fill Aquifers of the Southwest Principal Aquifers Study Area
}

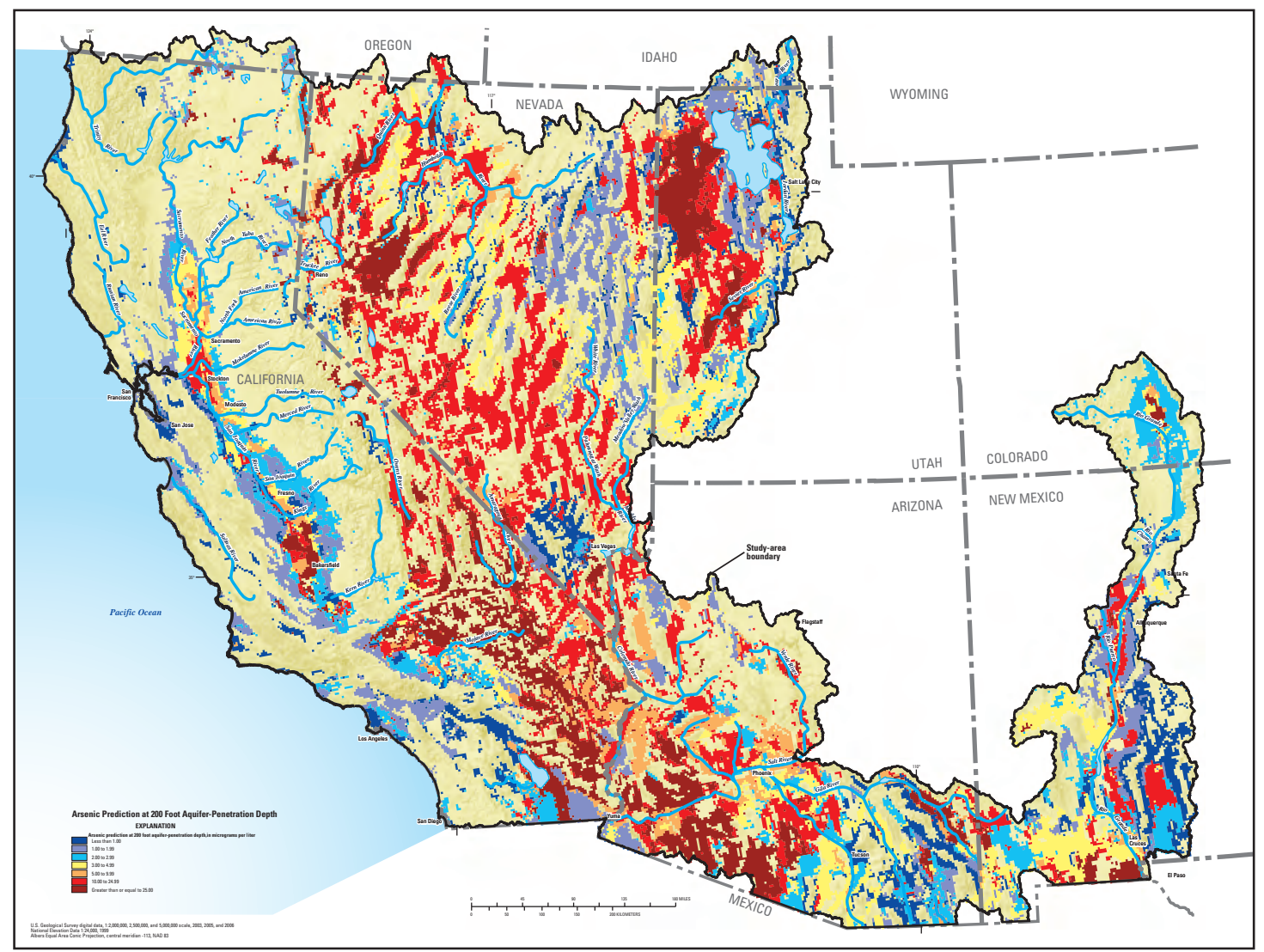

Data Series 698 



\section{Digital Spatial Data for Predicted Nitrate and Arsenic Concentrations in Basin- Fill Aquifers of the Southwest Principal Aquifers Study Area}

By Tim S. McKinney and David W. Anning

National Water-Quality Assessment Program

Data Series Report 698 


\section{U.S. Department of the Interior \\ KEN SALAZAR, Secretary \\ U.S. Geological Survey \\ Marcia K. McNutt, Director}

U.S. Geological Survey, Reston, Virginia: 2012

For more information on the USGS — the Federal source for science about the Earth, its natural and living resources, natural hazards, and the environment, visit http://www.usgs.gov or call 1-888-ASK-USGS.

For an overview of USGS information products, including maps, imagery, and publications, visit http://www.usgs.gov/pubprod

To order this and other USGS information products, visit http://store.usgs.gov

Any use of trade, product, or firm names is for descriptive purposes only and does not imply endorsement by the U.S. Government.

Although this report is in the public domain, permission must be secured from the individual copyright owners to reproduce any copyrighted materials contained within this report.

Suggested citation:

McKinney, T.S. and Anning, D.W., 2012, Digital spatial data for predicted nitrate and arsenic concentrations in basinfill aquifers of the Southwest Principal Aquifers study area: U.S. Geological Survey Data Series Report 698, 2 p.

Available at http://pubs.usgs.gov/ds/698. 


\section{Contents}

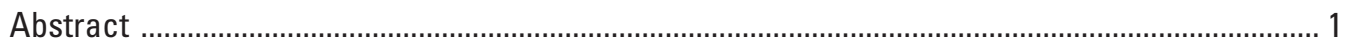

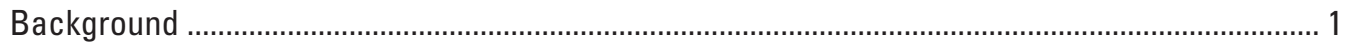

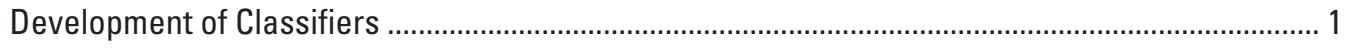

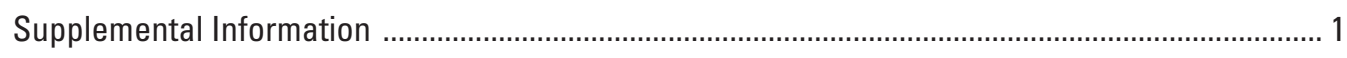

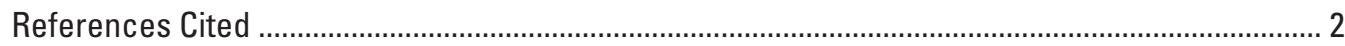




\section{Digital Spatial Data for Predicted Nitrate and Arsenic Concentrations in Basin-Fill Aquifers of the Southwest Principal Aquifers Study Area}

Abstract

This product "Digital spatial data for predicted nitrate and arsenic concentrations in basin-fill aquifers of the Southwest Principal Aquifers study area" is a 1:250,000-scale vector spatial dataset developed as part of a regional Southwest Principal Aquifers (SWPA) study (Anning and others, 2012). The study examined the vulnerability of basin-fill aquifers in the southwestern United States to nitrate contamination and arsenic enrichment. Statistical models were developed by using the random forest classifier algorithm to predict concentrations of nitrate and arsenic across a model grid that represents localand basin-scale measures of source, aquifer susceptibility, and geochemical conditions.

\section{Background}

This dataset was developed as part of a regional Southwest Principal Aquifers (SWPA) study and for the National Water-Quality Assessment (NAWQA) Program. The dataset represents the spatial and statistical distribution of nitrate and arsenic concentrations that were determined from the prediction classifiers for basin-fill aquifers across the SWPA study area.

\section{Development of Classifiers}

Separate classifiers were developed for nitrate and arsenic because each constituent was expected to be affected by a different set of factors, and each factor could have a different magnitude or directional influence (increase/decrease) on concentration. For each constituent, two different classifiers were developed: a prediction classifier and a confirmatory classifier. The prediction classifiers were developed specifically to predict nitrate and arsenic concentrations in basin-fill aquifers across the SWPA study area and were based on explanatory variables representing source and susceptibility conditions. These explanatory variables were available throughout the entire SWPA study area and, therefore, did not pose a limitation for using the classifiers to predict concentrations.
The confirmatory classifiers were developed to supplement the prediction classifiers in the evaluation of the conceptual model. The name, "confirmatory," reflects the classifier's purpose for evaluation of a-priori hypotheses and contrasts other general types of statistical models, such as those used for prediction or exploratory purposes. The confirmatory classifiers included the explanatory variables used in the prediction classifiers, as well as additional variables representing geochemical conditions and basin groundwater budget components. The inclusion of the geochemical and basin groundwater budget variables in the confirmatory classifiers allowed for further evaluation of the conceptual models, which was not possible with the prediction classifiers alone. The geochemical data, however, were only available at specific well locations, and consistent water-budget data were not available for every basin in the study area. The limited availability of the data for these variables constrained the confirmatory classifiers to observations from 16 case-study basins and precluded use of the confirmatory classifier for predicting concentrations across the SWPA study area. To contrast the scope of the two classifiers, the confirmatory classifiers were developed by using all available explanatory variables but with observations restricted to the 16 case-study basins, whereas the prediction classifiers were unrestricted with respect to spatial extent because these were developed by using a subset of the explanatory variables that were available throughout the study area.

\section{Supplemental Information}

The nitrate and arsenic predictions are part of a larger dataset of explanatory variables and model input data. Those data are archived in tabular form along with the model report. The explanatory data may be joined to this dataset via the grid cell identifier. For more information on the development of the explanatory variables, see "Compilation and Processing of Explanatory Variables" in the "Approach and Methods" section of Anning and others (2012).

The digital dataset can be downloaded from the USGS at http://water.usgs.gov/lookup/getspatial?ds2012-698_SWPA NO3_As_prediction. 


\section{References Cited}

Anning, D.W., Paul, A.P., McKinney, T.S., Huntington, J.M., Bexfield, L.M., and Thiros, S.A., 2012, Predicted nitrate and arsenic concentrations in basin-fill aquifers of the southwestern United States: U.S. Geological Survey Scientific Investigations Report 2012-5065, 78 p. Available at http://pubs.usgs.gov/sir/2012/5065. 


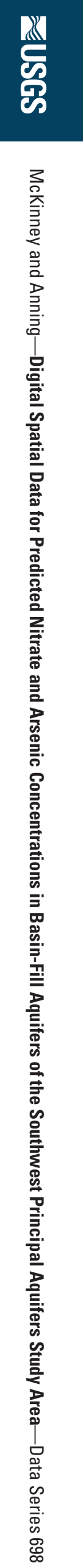